\title{
PENERAPAN MODEL PEMBELAJARAN VAN HIELE PADA MATERI HUBUNGAN GARIS DAN SUDUT DI KELAS VII SMP MUHAMMADIYAH 1 PALU
}

\author{
Fitriani $^{1)}$, Muh. Hasbi ${ }^{2)}$, Bakri $\mathbf{M}^{3 \text { ) }}$ \\ fitrifitefiteri@gmail.com ${ }^{1)}$, muhhasbi62@yahoo.co.id ${ }^{2}$, bakrim06@yahoo.co.id ${ }^{3)}$
}

\begin{abstract}
Abstrak: Tujuan penelitian ini adalah untuk mendeskripsikan penerapan model pembelajaran Van Hiele yang dapat meningkatkan hasil belajar siswa pada materi hubungan garis dan sudut di kelas VII SMP Muhammadiyah 1 Palu. Jenis penelitian yaitu penelitian tindakan kelas (PTK). Rancangan penelitian yang dilakukan mengacu pada desain penelitian Kemmis dan Mc. Taggart yang terdiri dari empat komponen, yaitu (1) perencanaan, (2) tindakan, (3) pengamatan, dan (4) refleksi. Penelitian ini dilaksanakan dalam dua siklus. Subjek penelitian ialah siswa kelas VII SMP Muhammadiyah 1 Palu pada tahun ajaran 2017/2018 yang berjumlah 25 siswa. Teknik pengumpulan data dalam penelitian ini yaitu observasi, tes, wawancara dan catatan lapangan. Hasil penelitian menunjukkan bahwa penerapan model pembelajaran Van Hiele dapat meningkatkan hasil belajar siswa dengan mengikuti fase-fase model pembelajaran Van Hiele, yakni: (1) inquiry, (2) orientasi terarah, (3) uraian, (4) orientasi bebas, dan (5) integrasi. Pada siklus I persentase ketuntasan belajar klasikal yaitu $47,83 \%$ dan pada siklus II persentase ketuntasan belajar klasikal meningkat menjadi $86,96 \%$. Selain itu, hasil pengamatan aktivitas guru dalam mengelolah pembelajaran pada siklus I maupun siklus II berada pada kategori sangat baik. Adapun hasil pengamatan aktivitas siswa dalam mengikuti proses pembelajaran pada siklus I berada pada kategori baik dan siklus II berada dalam kategori sangat baik.
\end{abstract}

Kata kunci: Model Pembelajaran Van Hiele, Hasil Belajar, Hubungan Garis dan Sudut

\begin{abstract}
The purpose of this study is to describe the application of the Van Hiele learning model that can improve student learning outcomes in the material relationship lines and angles in class VII Muhammadiyah Middle School 1 Palu. This type of research is classroom action research (CAR). The design of the study was based on the research design of Kemmis and Mc. Taggart consists of four components, namely (1) planning, (2) action, (3) observation, and (4) reflection. This research was conducted in two cycles. The research subjects were seventh grade students of Muhammadiyah Middle School 1 Palu in the 2017/2018 school year, totaling 25 students. Data collection techniques in this study were observation, tests, interviews, and field notes. The results showed that the application of the Van Hiele learning model could improve student learning outcomes by following the phases of Van Hiele's learning model, namely: (1) inquiry, (2) directed orientation, (3) description, (4) free orientation, and ( 5) integration. In the first cycle the percentage of classical learning completeness was $47.83 \%$ and in the second cycle the percentage of classical learning completeness increased to $86.96 \%$. In addition, the results of observations of teacher activities in managing learning in the first cycle and second cycle are in the very good category. The results of observations of student activities in following the learning process in the first cycle are in the good category and the second cycle is in a very good category.
\end{abstract}

Keywords: Van Hiele Learning Model, Learning Outcomes, Line and Angle Relations

Mata pelajaran matematika merupakan satu di antara mata pelajaran yang sulit dipelajari oleh siswa. Meskipun demikian, siswa di sekolah harus mempelajarinya karena matematika dapat membantu untuk memecahkan masalah dalam kehidupan sehari-hari.

Tujuan dari matematika yang diajarkan kepada siswa di sekolah antara lain mengembangkan kemampuan berpikir, mengembangkan penguasaan bahan ajar dan 
mengembangkan sikap positif terhadap matematika (Ratumanan, 2003). Oleh karena itu diperlukan usaha maksimal dari seorang peneliti matematika dan peneliti diharapkan dapat menyesuaikan antara materi yang akan diajarkan dengan tehnik pembelajaran yang akan diterapkan.

Berdasarkan hasil wawancara dengan guru bidang studi matematika SMP Muhammadiyah 1 Palu, diperoleh informasi bahwa dari sekian banyak materi pada pelajaran matematika yang dianggap sulit adalah konsep garis dan sudut, khususnya pada materi hubungan sudut pada dua garis sejajar yang dipotong oleh sebuah garis. Sebagian besar siswa kurang memahami konsep sudut sehadap, sudut dalam berseberangan, sudut luar berseberangan, sudut dalam sepihak dan sudut luar sepihak, sehingga siswa mengalami kesalahan dalam menyelesaikan soal-soal apabila bentuk soal tersebut dimodifikasi dan berbeda dengan contoh soal yang diberikan sebelumnya.

Menindaklanjuti hasil wawancara dengan guru matematika di SMP Muhammadiyah 1 Palu, peneliti melakukan tes identifikasi masalah kepada siswa kelas VIII SMP Muhammadiyah 1 Palu yang terdaftar pada semester ganjil tahun ajaran 2017/2018. Adapun soal yang peneliti sajikan pada tes identifikasi masalah antara lain: Diketahui garis $m$ dan $n$ sejajar dan dipotong oleh garis $g$ dan $h$. 1) hitunglah besar sudut $M$, sudut T, sudut B dan sudut R!, 2) tuliskanlah pasangan sudut-sudut dalam berseberangannya!

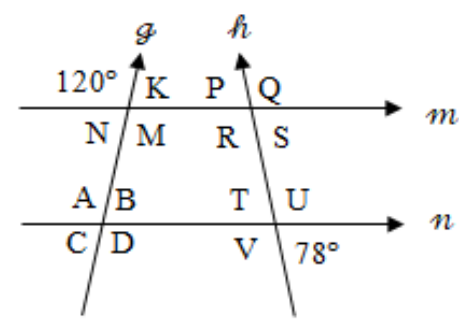

Gambar 1. Gambar pada Soal

$$
\begin{aligned}
& \angle R=120^{\circ}+\angle R=180^{\circ}=60^{\circ} \\
& \angle T=180^{\circ}+\angle T=180=10^{\circ} \\
& \angle B=120^{\circ}+70^{\circ}=190^{\circ}
\end{aligned}
$$

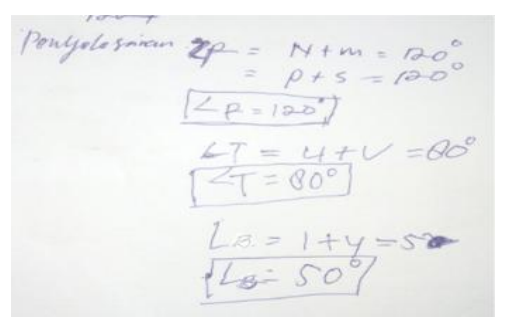

(ii)

Tes Identifikasi

Gambar 2. Kelompok Jawaban Siswa

Berdasarkan Kesalahan

Jawaban siswa terhadap soal tersebut dikelompokkan berdasarkan kesalahan yang dilakukan oleh siswa. Soal dan kelompok jawaban siswa masing-masing ditunjukkan oleh Gambar 1 dan 2.

Berdasarkan Gambar 2 terlihat jawaban siswa yang langsung menjumlahkan besar sudut yang diketahui dengan sudut yang ditanyakan. Banyaknya siswa yang menjawab seperti Gambar 2 (i) dan Gambar 2 (ii) masing-masing 8 siswa dan 2 siswa.

Berdasarkan jawaban siswa, peneliti memandang bahwa siswa belum mampu mengaitkan konsep-konsep pada materi sebelumnya dan tidak memahami konsep yang telah diberikan pada materi sudut-sudut yang terbentuk jika dua garis sejajar dipotong oleh sebuah garis dan hubungan sifat sudut pada dua garis sejajar yang dipotong oleh garis lain.

Berdasarkan jawaban siswa untuk soal nomor 2 yaitu dari 18 siswa yang mengikuti tes identifikasi hanya terdapat 1 siswa yang menjawab soal dengan benar dan siswa lainnya masih melakukan kesalahan dalam menuliskan pasangan-pasangan sudut dalam berseberangannya.

Berdasarkan masalah yang diperoleh, dapat disimpulkan bahwa kesalahankesalahan tersebut disebabkan karena siswa kurang memahami konsep tentang materi hubungan garis dan sudut. Peneliti berasumsi bahwa permasalahan tersebut disebabkan karena siswa cenderung hanya menghafal sifat-sifat sudut yang terjadi jika dua garis sejajar 
dipotong oleh garis lain tanpa memahami konsepnya. Selain itu berdasarkan wawancara dengan guru matematika, selama pembelajaran siswa menerima pengetahuan yang bersumber dari guru sepenuhnya tanpa mengkontruksi pemahamannya sendiri, sehingga bila diberikan soal-soal yang lebih variatif maka siswa tidak mampu untuk menyelesaikannya. Peneliti berasumsi bahwa kejadian yang dialami siswa kelas VIII ini juga akan terjadi pada siswa kelas VII.

Salah satu upaya yang dapat dilakukan untuk mengatasi permasalahan di atas adalah dengan menerapkan model pembelajaran Van Hiele. Menurut Thohari (2010) bahwa model pembelajaran Van Hiele adalah salah satu model pembelajaran yang cocok digunakan pada materi geometri karena selain memberikan kesempatan kepada siswa untuk mengkontruksi sendiri pengetahuannya, model pembelajaran Van Hiele juga dapat merespon kebutuhan semua siswa yang mungkin bervariasi dalam tingkat berpikir dan kemampuan geometrinya. Hal ini disebabkan oleh model pembelajaran Van Hiele menawarkan lima tahapan pembelajaran, yaitu: (1) inquiry, (2) orientasi terarah, (3) uraian, (4) orientasi bebas, dan (5) integrasi. Melalui penerapan model pembelajaran Van Hiele, peneliti mengharapkan siswa dapat memahami sifat-sifat sudut yang terjadi bila dua garis sejajar dipotong oleh garis lain, sehingga dapat pula meningkatkan hasil belajar siswa.

Rumusan masalah dalam penelitian yaitu bagaimana penerapan model pembelajaran Van Hiele dapat meningkatkan hasil belajar siswa pada materi hubungan garis dan sudut di kelas VII SMP Muhammadiyah 1 Palu? Tujuan penelitian ini untuk mendeskripsikan penerapan model pembelajaran Van Hiele yang dapat meningkatkan hasil belajar siswa pada materi hubungan garis dan sudut di kelas VII SMP Muhammadiyah 1 Palu.

\section{METODE PENELITIAN}

Jenis penelitian ini ialah penelitian tindakan kelas yang mengacu pada alur desain penelitian yang dikemukakan oleh Kemmis dan Mc. Taggart (Arikunto: 2007), yang direncanakan dalam 2 siklus. Setiap siklus dilakukan dengan melalui 3 tahap, yaitu perencanaan (planning), pelaksanaan tindakan dan observasi (acting\& observing), refleksi (reflection). Tahap pelaksanaan tindakan dan observasi dilakukan pada satu waktu yang sama.

Subjek penelitian yakni siswa kelas VII SMP Muhammadiyah 1 Palu sebanyak 25 siswa yang terdaftar pada tahun ajaran 2017/2018. Kemudian, dari subjek penelitian dipilih 3 siswa sebagai informan yaitu: satu siswa berkemampuan tinggi berinisial KK, satu siswa berkemampuan sedang berinisial AHD dan satu siswa berkemampuan rendah berinisial RMU. Teknik analisis data terdiri dari kondensasi data, menyajikan data dan penarikan kesimpulan.

Kegiatan peneliti dan siswa dalam proses pembelajaran dengan menggunakan model pembelajaran Van Hiele dapat dinyatakan berhasil apabila total skor yang diperoleh berada dalam kategori baik atau sangat baik. Tindakan dikatakan berhasil jika persentase ketuntasan belajar minimum 75\% (Aqib, 2009), dengan ketuntasan individu minimal 75 (berdasarkan KKM yang diterapkan di SMP Muhammadiyah 1 Palu)

\section{HASIL PENELITIAN}

Hasil penelitian ini terdiri atas dua bagian, yaitu hasil pratindakan dan hasil pelaksanaan tindakan. Pada pelaksanaan pratindakan, peneliti melakukan tes awal kepada siswa kelas VII yang berjumlah 23 orang siswa. Hasil tes awal menunjukkan bahwa siswa 
dapat menentukan jenis-jenis sudut yang meliputi sudut lancip, sudut tumpul dan sudut siku-siku tanpa melakukan pengukuran dan menentukan garis-garis sejajar. Namun, sebagian siswa belum memahami materi hubungan antar sudut. Oleh karena itu, peneliti membantu siswa dalam mempelajari materi hubungan antar sudut yang belum dimiliki pada kegiatan awal dalam pembelajaran. Adapun tujuan dari tes awal yakni untuk melihat kemampuan prasyarat siswa dan untuk membentuk kelompok-kelompok belajar yang heterogen.

Penelitian ini terdiri atas dua siklus. Setiap siklus dilaksanakan dalam dua kali pertemuan. Kegiatan pada pertemuan pertama siklus I yaitu melaksanakan pembelajaran dengan materi sudut-sudut yang terbentuk jika dua garis sejajar dipotong oleh garis lain. Kegiatan pada pertemuan kedua memberikan tes akhir tindakan siklus I. Pertemuan pertama pada siklus II yaitu melaksanakan pembelajaran dengan materi sifat-sifat sudut yang terbentuk jika dua garis sejajar dipotong oleh garis lain. Pertemuan kedua memberikan tes akhir tindakan siklus II. Pertemuan pertama pada siklus I dan siklus II dilaksanakan dalam tiga tahap, yaitu 1) kegiatan pendahuluan, 2) kegiatan inti, dan 3) kegiatan penutup. Pelaksanaan tindakan setiap siklus mengikuti fase-fase model pembelajaran Van Hiele, yaitu 1) informasi, 2) orientasi terarah, 3) uraian, 4) orientasi bebas, dan 5) integrasi.

Kegiatan pendahuluan dimulai dengan peneliti membuka pembelajaran dengan mengucapkan salam, mengajak siswa untuk berdoa bersama, mengecek kehadiran siswa dan menyiapkan siswa untuk belajar. Kegiatan tersebut dapat menarik perhatian siswa di awal pembelajaran. Hal ini dapat dilihat saat siswa memberikan respon balik terhadap kegiatan yang dilakukan oleh peneliti. Pertemuan pertama dan kedua pada siklus I dihadiri oleh 23 siswa karena 2 siswa sakit kemudian pada pertemuan pertama dan kedua siklus II dihadiri oleh 23 siswa, karena 1 siswa sakit dan 1 orang siswa lainnya tanpa keterangan. Kemudian peneliti menyampaikan tujuan pembelajaran yang hendak dicapai. Tujuan pembelajaran pada siklus I yaitu siswa dapat menemukan sudut-sudut sehadap, menemukan sudut-sudut dalam berseberangan, menemukan sudut-sudut luar berseberangan, menemukan sudut-sudut dalam sepihak dan menemukan sudut-sudut luar sepihak, sedangkan tujuan pembelajaran pada siklus II yaitu siswa dapat menemukan sifat-sifat sudut jika dua garis sejajar dipotong garis lain dan menggunakan sifat-sifat sudut dan garis untuk menyelesaikan soal. Pada kegiatan ini siswa telah mengetahui tujuan pembelajaran yang hendak dicapai sehingga siswa terarah dalam mengikuti pembelajaran

Peneliti memotivasi siswa dengan menyampaikan manfaat mempelajari materi hubungan garis dan sudut dalam kehidupan sehari-hari. Setelah siswa mengetahui manfaat mempelajari materi hubungan garis dan sudut, siswa termotivasi untuk mengikuti pembelajaran. Kemudian, peneliti melakukan apersepsi dengan mengingatkan kembali kepada siswa mengenai materi prasyarat. Materi prasyarat pada siklus I ialah konsep sudut dan garis sejajar, sedangkan materi prasyarat pada siklus II ialah hubungan antar sudut. Siswa dapat menguasai materi konsep sudut, garis sejajar, dan hubungan antar sudut yang merupakan materi prasyarat dari materi hubungan garis dan sudut. Siswa yang menguasai materi prasyarat tidak mengalami kesulitan dalam mempelajari materi hubungan garis dan sudut.

Kegiatan inti diawali dengan pelaksanaan fase inquiry. Kegiatan fase inquiry siklus I yaitu peneliti meminta siswa untuk membedakan contoh konkrit dua garis sejajar, contoh konkrit tersebut yaitu gambar rel kereta api, jarum jam yang menunjukkan pukul 12.00 dan jarum jam yang menunjukkan pukul 14.00. Selanjutnya peneliti menjelaskan gambaran kedudukan dua buah garis sejajar melalui contoh konkrit yang menunjukkan dua buah garis sejajar dan mengilustrasikannya kedalam geometri serta contoh garis sejajar yang dipotong 
oleh garis lain dan mengilustrasikannya kedalam geometri. Kegiatan fase inquiri siklus II yaitu peneliti memberikan gambaran dua garis sejajar dipotong garis lain melalui contoh konkrit dan siswa diminta untuk mengelompokkan yang termasuk contoh dua garis sejajar dipotong oleh garis lain, seperti gambar permainan roller coaster, jalan tol, anyaman dan rel kereta api. Selanjutnya peneliti menampilkan salah satu contoh konkrit yang menunjukkan dua garis sejajar dipotong oleh garis lain dan mengilustrasikannya kedalam geometri. Kemudian peneliti menjelaskan dua garis sejajar dan dipotong oleh garis lain dan jenis-jenis sudut yang terbentuk serta mengilustrasikannya kedalam bentuk geometri. Ilustrasi-ilustrasi yang digunakan oleh peneliti saat fase inquiry ditunjukkan pada Gambar 3, 4, 5 dan 6 .

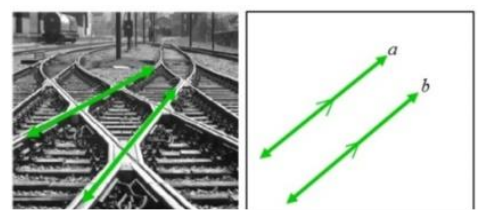

Gambar 3. Ilustrasi dua garis sejajar

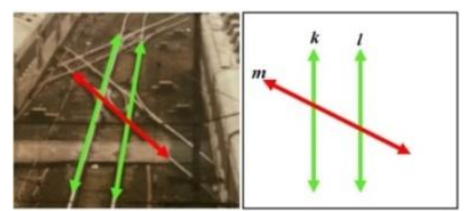

Gambar 5. Ilustrasi dua garis sejajar dipotong oleh garis lain

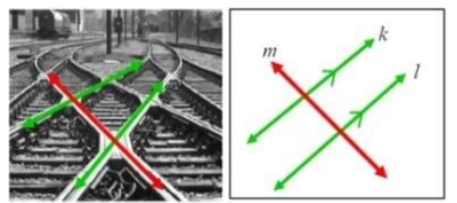

Gambar 4. Ilustrasi dua garis sejajar dipotong garis lain

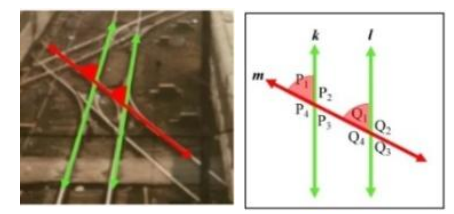

Gambar 6. Ilustrasi dua garis sejajar dipotong oleh garis lain dan jenis-jenis sudut yang terbentuk

Capaian siswa pada fase inquiry yaitu siswa terdorong untuk mengamati gambar yang diberikan dengan adanya pertanyaan yang diajukan oleh peneliti, sehingga siswa telah mengetahui informasi awal tentang materi hubungan garis dan sudut. Pada siklus I siswa mengetahui bahwa ada sudut yang terbentuk jika dua garis sejajar dipotong oleh garis lain, sedangkan pada siklus II siswa dapat mengetahui pasangan sudut-sudut yang terbentuk jika dua garis sejajar dipotong oleh garis lain. Hal ini dapat memudahkan peneliti dalam mengarahkan siswa pada fase selanjutnya.

Aktivitas pada fase orientasi terarah ialah peneliti mengajak siswa bergabung ke dalam kelompok belajar yang telah dibentuk sebelumnya. Siswa dibentuk ke dalam 5 kelompok belajar dengan kelompok I, II, III, IV dan V masing-masing beranggotakan siswa 4-5 orang. Selanjutnya peneliti membagikan LKS kepada setiap kelompok. Pada siklus I setiap kelompok mengerjakan LKS yang berisi langkah-langkah untuk menentukan pasangan sudut yang terbentuk jika dua garis sejajar dipotong oleh garis lain. Semua kelompok aktif dalam mengerjakan LKS. Terdapat dua kelompok yang aktif bertanya yaitu kelompok I dan kelompok III. Pada siklus II semua kelompok aktif bertanya, hal ini terlihat dari siswa yang sudah berani untuk menanyakan hal-hal yang belum dipahaminya pada peneliti dan mampu mengungkapkan pengetahuan mereka dalam mengerjakan LKS. Ada beberapa kelompok yang mengerjakan LKS dengan membagi tugas yaitu kelompok I, II dan IV. Selain itu peneliti juga menemukan beberapa kelompok yang kesulitan dalam memberikan kesimpulan diantaranya yaitu kelompok II dan V, peneliti memberikan bimbingan sehingga siswa dapat membuat kesimpulan dengan tepat.

Aktivitas pada fase uraian yakni siswa mempresentasikan hasil kerja kelompok yang diperoleh dari kegiatan pada fase sebelumnya. Pada siklus I terdapat 3 siswa yang bersedia mempresentasikan hasil kerja kelompoknya tanpa ditunjuk, yaitu siswa ZN untuk 
mempresentasikan jawaban soal nomor 1 , KK mempresentasikan jawaban soal nomor 2 dan NM untuk mempresentasikan jawaban soal nomor 3. Selanjutnya peneliti memilih siswa AS dari kelompok II untuk mempresentasikan jawaban soal nomor 4 dan siswa AM dari kelompok III untuk mempresentasikan jawaban nomor 5. Kemudian siswa AHD dari kelompok I bersedia memberikan kesimpulan tanpa harus ditunjuk oleh peneliti. Pada siklus II peneliti mempersilahkan siswa yang bersedia mempresentasikan hasil kerja kelompoknya terlebih dahulu, terdapat 4 siswa yang bersedia yaitu AHD dari kelompok I, FD dari kelompok III, RMU dari kelompok IV dan ABM dari kelompok V, selanjutnya peneliti memilih siswa TR perwakilan dari kelompok II. Peneliti mempersilahkan siswa maju mempresentasikan jawabannya sesuai dengan nomor urut kelompok masing-masing.

Capaian siswa fase uraian ialah siswa mampu mengungkapkan hasil kerja kelompok melalui presentasi di depan kelas dan berkesempatan untuk mengubah pengetahuan yang masih keliru melalui arahan peneliti. Selain itu siswa mampu menanggapi hasil presentasi kelompok penyaji dengan mengemukakan pendapat di depan kelas, sehingga materi yang dipelajari lebih berkesan bagi siswa

Kemudian aktivitas pada fase orientasi bebas ialah peneliti memberikan soal-soal kepada siswa yang dikerjakan secara individu. Pada siklus I siswa mengerjakan soal tentang sudut-sudut yang terbentuk jika dua garis sejajar dipotong oleh garis lain dan pada siklus II siswa mengerjakan soal dengan menggunakan sifat-sifat sudut yang terbentuk jika dua garis sejajar dipotong oleh garis lain. Capaian siswa pada fase ini yaitu siswa mampu menyelesaikan soal-soal yang diberikan secara mandiri. Kegiatan ini memberikan kesempatan kepada siswa untuk memperoleh pengalaman langsung dalam menyelesaikan soal dengan strategi sendiri, sehingga dapat memantapkan pengetahuan siswa tentang materi hubungan garis dan sudut

Fase integrasi dilaksanakan pada kegiatan penutup pembelajaran. Peneliti mengarahkan siswa untuk membuat rangkuman materi hubungan garis dan sudut. Pada siklus I siswa membuat rangkuman tentang sudut-sudut yang terbentuk jika dua garis sejajar dipotong oleh garis lain. Pada siklus II siswa membuat rangkuman tentang sifat-sifat sudut yang yang terbentuk jika dua garis sejajar dipotong oleh garis lain.

Capaian siswa pada fase integrasi ialah siswa mampu menyimpulkan materi yang dipelajari secara tertulis. Selanjutnya peneliti berpesan kepada siswa agar tetap belajar karena pertemuan selanjutnya ialah pemberian tes. Setelah itu peneliti mengakhiri kegiatan pembelajaran dengan mengucapkan salam.

Peneliti memberikan tes akhir tindakan kepada siswa setelah melaksanakan pembelajaran. Tes akhir tindakan pada siklus I terdiri atas dua nomor soal. Satu diantara soal yang diberikan yaitu sebagaimana ditunjukkan pada Gambar 7.
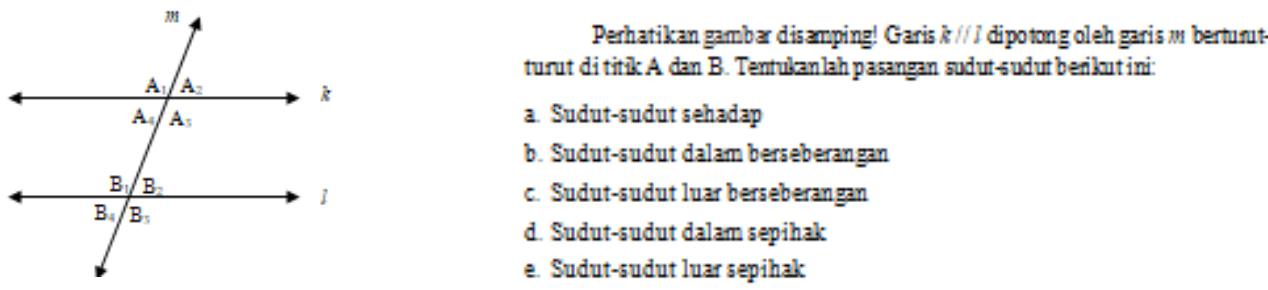

Gambar 7. Soal tes akhir tindakan siklus I

Hasil tes akhir tindakan siklus I menunjukkan bahwa dari 23 siswa yang mengikuti tes akhir tindakan, hanya 8 siswa yang menjawab soal dengan benar dan 15 siswa lainnya melakukan kesalahan dalam menentukan pasangan sudut yang terbentuk jika dua garis 
sejajar dipotong oleh garis lain. Satu diantara siswa yang melakukan kesalahan yaitu siswa RMU. Berikut jawaban siswa RMU sebagaimana ditunjukkan pada Gambar 8.

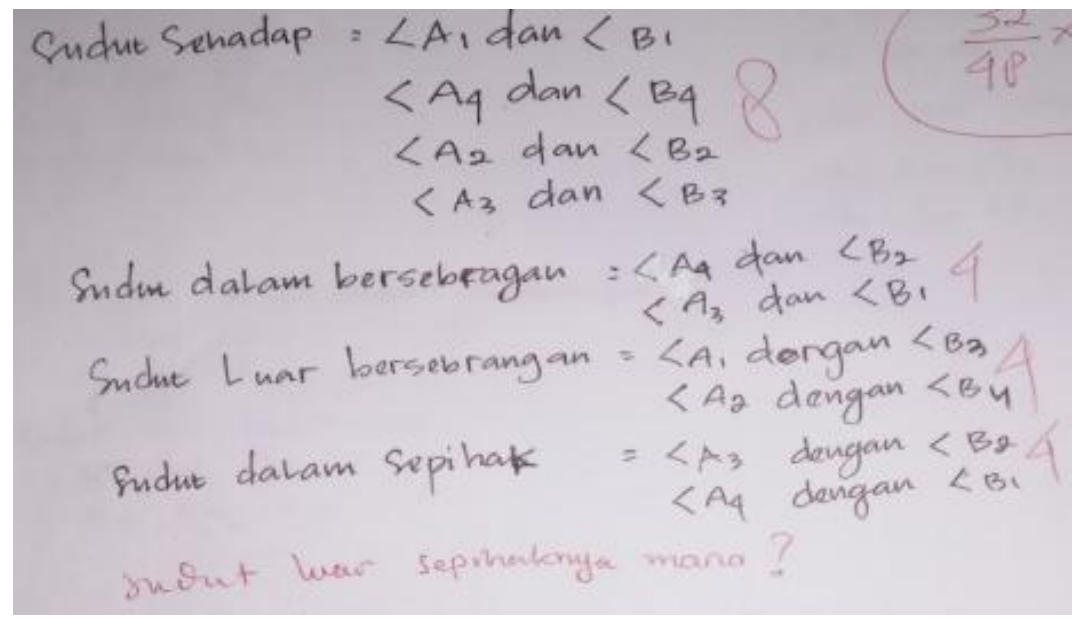

Gambar 8. Jawaban siswa RMU terhadap soal tes akhir tindakan siklus I

Gambar 8 menunjukkan bahwa siswa RMU tidak menuliskan pasangan pasangan sudut-sudut luar sepihaknya. Siswa RMU seharusnya menuliskan pasangan sudut-sudut luar sepihaknya yaitu $\angle A_{1}$ dengan $\angle B_{4}$.

Peneliti melakukan wawancara dengan siswa RMU untuk memperoleh informasi lebih lanjut tentang kesalahan RMU. Kutipan wawancara peneliti dengan RMU adalah sebagai berikut:

Peneliti : Oh, iya dek. Kakak lihat di lembar jawaban ujiannya kemarin, disoal nomor satu ade tidak menuliskan sudut luar sepihaknya. Kenapa begitu dek?

RMU : Hehehe, kemarin itu saya lupa kak

Peneliti : Jadi jawabannya disitu apa dek?

RMU $\quad: \angle A_{1}$ dan $\angle A_{2}$ kak

Peneliti : Coba diperhatikan lagi dek! Yang dikatakan sudut sepihak itu yang bagaimana

RMU : Oh, yang sepihak itu $\angle A_{1}$ dan $\angle B_{4}$

Peneliti : Iya dek. Itu jawabannya. Sekarang adek periksa nomor 2 bagian c, d dan e! adek bisa perbaiki sendirikan jawabannya?

Hasil wawancara pada siklus I memberikan informasi bahwa siswa sebenarnya masih bingung dalam menentukan pasangan sudut luar sepihak, selain itu siswa juga kurang teliti dalam mengerjakan soal, tetapi siswa dapat mengerjakan soal dengan benar setelah dituntun oleh peneliti untuk mengerjakan kembali.

Tes akhir tindakan pada siklus II terdiri atas tiga nomor soal yang diikuti oleh 23 siswa. Satu diantara soal tes akhir tindakan siklus II ditunjukkan pada Gambar 9. Salah satu siswa yang belum menggunakan sifat-sifat sudut yang terbentuk jika dua garis sejajar dipotong oleh garis lain adalah siswa RMU. Jawaban siswa RMU terhadap soal tersebut ditunjukkan pada Gambar 10. 
Perhatikan gambar berikut diketahui garis $m$ sejajar dengan garis $n$, makatentukan nilai $x$ pada gambar berikut !

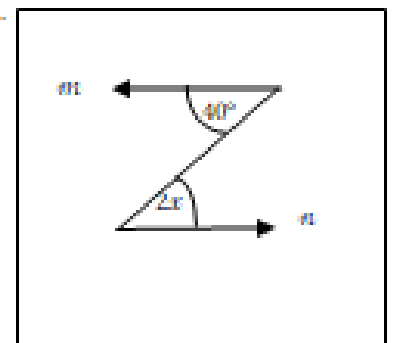

Gambar 9. Soal tes akhir tindakan siklus II

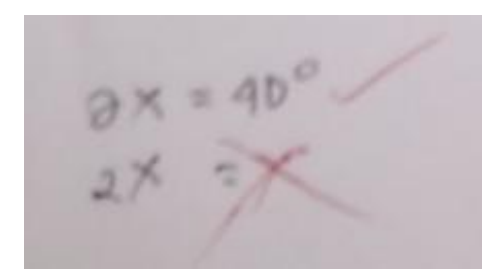

Gambar 10. Jawaban siswa RMU terhadap soal tes akhir tindakan siklus II

Peneliti melakukan wawancara dengan siswa RMU untuk memperoleh informasi lebih lanjut tentang kesalahan RMU. Kutipan wawancara peneliti dengan RMU ialah sebagai berikut:

Peneliti : Terus kenapa saat ulangan adek tidak menyelesaikan soal nomor 3?

RMU : Saya tidak tau kak, saya bingung mau dikerjakan bagaimana

Peneliti : Nah, sekarang coba adek perhatikan lagi gambarnya

RMU : O, iya kak

Peneliti : Coba adek perhatikan sudut yang terbentuk itu sudut apa?

RMU : : Sudut dalam berseberangan kak

Peneliti : Jadi kalau sudut dalam berseberangan itu artinya apa dek?

RMU : Jadi ukuran sudutnya sama besar kak

Peneliti : nah, sekarang coba adek lanjutkan sampai dpat nilai x nya

RMU : Iya kak. Jadi, $2 x=40^{\circ}$. Terus $x=\frac{40^{\circ}}{2}$

Peneliti : Berapa hasilnya dek?

RMU : nilai $x$ nya itu $20^{\circ} \mathrm{kak}$

Hasil wawancara dengan siswa RMU memberikan informasi bahwa siswa RMU dapat memahami soal. Namun, RMU masih ragu-ragu dalam menyelesaikan soal dengan menggunakan sifat-sifat sudut yang terbentuk jika dua garis sejajar dipotong oleh garis lain. Tapi setelah siswa dituntun untuk mengerjakan kembali, siswa dapat menyelesaikan soal dengan benar.

Hasil tes akhir tindakan dan wawancara pada setiap siklus menunjukkan bahwa siswa dapat menyelesaikan soal tentang sudut-sudut yang terbentuk jika dua garis sejajar dipotong oleh garis lain dan siswa dapat menggunakan sifat-sifat sudut yang terbentuk jika dua garis sejajar dipotong oleh garis lain. Namun, masih ada siswa yang melakukan kesalahan dalam menyelesaikan soal yang diberikan. Setelah peneliti menuntun siswa untuk mengerjakan soal kembali, siswa dapat mengerjakan soal dengan benar.

Setelah menganalisis hasil tes akhir tindakan siklus I maupun siklus II dan melakukan wawancara dengan informan untuk mengetahui pemahaman siswa dalam menyelesaikan soal-soal tes yang diberikan diperoleh informasi yang beragam tentang pemahaman informan dalam menyelesaikan soal tes akhir tindakan yang diberikan. Selanjutnya, hasil pekerjaan siswa setelah diperiksa diperoleh 11 siswa yang tuntas dan 12 siswa yang tidak tuntas pada siklus I. Persentase ketuntasan klasikal sebesar 47,83\%. Hasil yang diperoleh 
dari tes akhir tindakan siklus II yaitu banyak siswa yang tuntas adalah 20 siswa dan 3 siswa yang tidak tuntas. Persentase ketuntasan klasikal sebesar $86,96 \%$.

Aspek-aspek aktivitas peneliti yang diamati selama pembelajaran berlangsung pada siklus I dan siklus II menggunakan lembar observasi meliputi: 1) mengajukan pertanyaan kepada siswa sambil melakukan observasi, 2) mengambil salah satu contoh konkrit yang menunjukkan garis sejajar dan mengilustrasikannya ke dalam geometri, 3) menjelaskan kepada siswa tentang contoh garis yang sejajar dipotong oleh garis lain, 4) meminta siswa untuk berkelompok dimana tiap kelompok terdiri dari 4-5 orang siswa sesuai dengan kelompok yang telah dibagi serta membagikan Lembar Kerja Siswa (LKS) kepada tiap-tiap kelompok, 5) menjelaskan petunjuk mengerjakan LKS, 6) memonitor jalannya diskusi kelompok dan memberikan bantuan seperlunya, 7) memilih perwakilan siswa dari beberapa kelompok untuk memaparkan hasil kerja kelompoknya dan memberikan kesempatan kepada kelompok lain untuk menanggapinya, 8) membimbing siswa menggunakan bahasa yang tepat dan akurat dalam mempresentasikan hasil diskusinya, 9) membimbing siswa menggunakan bahasa yang tepat dan akurat untuk menjelaskan apa yang diamati siswa pada LKS, 10) memberikan tugas yang lebih kompleks kepada siswa mengenai sudut-sudut yang terbentuk jika dua garis sejajar dipotong oleh garis lain yang terdapat pada LKS, 11) mengoreksi jawaban siswa, 12) mengarahkan siswa untuk membuat rangkuman konsep yang dipelajari dengan mengungkapkan melalui tulisan, 13) mengumpulkan tugas yang diberikan yakni rangkuman tentang konsep yang dipelajari.

Hasil observasi aktivitas peneliti pada siklus I oleh pengamat adalah aspek 1, 4, 5, 6, 10, 12, dan 13 memperoleh nilai 5. Aspek 2, 3, 7, 8, 9, dan 11 memperoleh nilai 4 . Persentase nilai rata-rata yang diperoleh adalah $90,76 \%$ sehingga aktivitas peneliti pada siklus I masuk kategori sangat baik. Sedangkan hasil observasi aktivitas peneliti pada siklus II yaitu aspek 1, 2, 4, 5, 6, 7, 10, 12 dan 13 memperoleh nilai 5. Aspek 3, 8, 9 dan 11 memperoleh nilai 4. Karena persentase nilai rata-rata yang diperoleh adalah 93,84\% maka disimpulkan bahwa aktivitas peneliti pada siklus II masuk kategori sangat baik.

Aspek-aspek aktivitas siswa yang diamati selama pembelajaran berlangsung pada siklus I dan II menggunakan lembar observasi meliputi: 1) memperhatikan pertanyaan peneliti serta menjawab pertanyaan peneliti, 2) memperhatikan contoh konkrit yang ditunjukkan peneliti dan menjawab pertanyaan peneliti untuk mengilustrasikannya ke dalam geometri, 3) memperhatikan penjelasan peneliti tentang dua garis sejajar dipotong garis lain dan jenis-jenis sudut yang terbentuk dan menanggapinya, 4) membentuk kelompok sesuai dengan arahan peneliti dan menerima LKS dengan tertib, 5) memperhatikan penjelasan peneliti, 6) bekerja sama dengan teman kelompok untuk mengerjakan LKS dan meminta bantuan kepada peneliti jika mengalami kesulitan, 7) memilih perwakilan kelompok untuk mempresentasikan hasil diskusi kelompoknya bagi kelompok yang ditunjuk dan kelompok lain menanggapinya, 8) mempresentasikan hasil diskusi kelompoknya yakni mengungkapkan ide-idenya tentang materi yang dikerjakan pada LKS dengan menggunakan bahasanya sendiri, 9) memperhatikan presentasi temannya dan memberikan tanggapan serta memperhatikan penjelasan dari peneliti agar menggunakan bahasa yang tepat dan akurat untuk menjelaskan apa yang diamati pada LKS, 10) mengerjakan tugas mengenai mengenai sifat-sifat sudut yang terbentuk jika dua garis sejajar dipotong oleh garis lain yang terdapat pada LKS dan siswa yang mampu mengerjakan akan mempresentasikan jawabannya, 11) memperhatikan pengoreksian jawaban yang dilakukan peneliti, 12) membuat rangkuman tentang konsep yang dipelajari melalui tulisan, 13) mengumpulkan tugas yang dikerjakan yakni rangkuman tentang konsep yang dipelajari. 
Hasil observasi aktivitas siswa pada siklus I yaitu aspek 4 memperoleh nilai 5 . Aspek 1, 3, 5, 6, 8, 10, 12, dan 13 memperoleh nilai 4. Aspek 2, 7, 9 dan 11 memperoleh nilai 3. Persentase nilai rata-rata yang diperoleh adalah $75,38 \%$ masuk dalam kategori baik. Hasil observasi aktivitas siswa pada siklus II yaitu aspek 4, 7, 12 dan 13 memperoleh nilai 5. Aspek 1, 2, 3, 5, 6, 8, 9,10 dan 11 memperoleh nilai 4. Persentase nilai rata-rata yang diperoleh adalah $86,15 \%$, sehingga aktivitas siswa pada siklus II masuk kategori sangat baik.

\section{PEMBAHASAN}

Kegiatan yang dilakukan pada tahap pratindakan yaitu peneliti memberikan tes awal kepada siswa untuk mengetahui kemampuan awal siswa pada materi prasyarat. Hasil tes awal digunakan sebagai pedoman untuk membentuk kelompok belajar dan penentuan informan dalam penelitian. Hal ini sesuai dengan pendapat Palolang (2014) bahwa pemberian tes awal sebelum pelaksanaan tindakan bertujuan untuk mengetahui kemampuan siswa pada materi prasyarat dan sebagai pedoman dalam pembentukan kelompok belajar yang heterogen serta penentuan informan. Selanjutnya peneliti menentukan tiga orang informan dengan kemampuan yang heterogen, yaitu tinggi, sedang dan rendah. Pengambilan informan didasarkan dari hasil analisis tes awal dan pertimbangan dari guru matematika. Hal ini dimaksudkan untuk memperoleh informasi mengenai kesulitan yang dihadapi siswa dalam mengikuti pembelajaran.

Kegiatan pembelajaran dimulai dengan menyampaikan tujuan dan mempersiapkan siswa dimulai dengan membuka kegiatan pembelajaran dengan mengucapkan salam, berdoa bersama, mengecek kehadiran siswa dan mempersiapkan siswa untuk belajar. Selanjutnya peneliti memotivasi siswa dengan cara menjelaskan manfaat mempelajari materi yang akan dipelajari. Hal ini sesuai dengan pendapat Uno (2007) yang menyatakan bahwa siswa akan termotivasi untuk belajar apabila mengetahui manfaat dari apa yang dipelajari.

Peneliti menyampaikan cakupan materi dan tujuan pembelajaran agar siswa termotivasi untuk berusaha mencapai tujuan pembelajaran yang diinginkan. Hal ini sesuai dengan pendapat Barlian (2013) yang menyatakan bahwa cakupan materi dan penyampaian tujuan pembelajaran sebelum memulai pembelajaran merupakan strategi yang dapat memotivasi siswa untuk berusaha mencapai tujuan pembelajaran yang diinginkan.

Fase inquiry merupakan fase awal yang diisi dengan kegiatan tanya jawab antara peneliti dan siswa mengenai objek-objek geometri. Peneliti memberikan gambaran tentang kedudukan dua garis pada siklus I dan dua garis sejajar dipotong oleh garis lain pada siklus II melalui contoh konkrit. Contoh konkrit yang diberikan berupa contoh dan bukan contoh sehingga siswa dapat membedakan suatu objek dengan objek lain seperti yang dikemukakan oleh Khotimah (2013) bahwa bila siswa dapat menunjukkan yang contoh dan bukan contoh maka siswa dapat membedakan suatu objek dengan objek lain.

Fase orientasi terarah dilakukan peneliti dengan mengelompokkan siswa ke dalam 5 kelompok belajar. Setiap kelompok terdiri dari 4-5 orang siswa. Pembagian kelompok bertujuan untuk mempermudah siswa melakukan aktivitas penemuan, karena siswa dapat bertukar ide dengan teman sekelompoknya. Hal ini sesuai dengan pendapat Karim (2011) yang menyatakan bahwa dengan adanya pembagian kelompok maka akan mempermudah siswa melakukan aktivitas penemuan, karena siswa dapat berinteraksi dengan siswa lainnya.

Peneliti juga memberikan LKS terstruktur pada saat pembelajaran siklus I dan siklus II. LKS diberikan kepada setiap kelompok yang bertujuan untuk menuntun siswa dalam 
menggali informasi dan melakukan eksplorasi tentang materi yang diajarkan. Hal ini sesuai dengan pendapat Safrina, dkk (2014) "tugas yang diberikan berupa LKS yang disusun sedemikian sehingga siswa secara aktif dirangsang untuk menggali dan mengeksplorasi objek-objek kajiannya (misalnya memutar, mengukur, melipat) untuk menemukan hubungan prinsip." Dalam LKS tersebut terdapat sejumlah pertanyaan yang disusun secara sistematis sehingga dapat membantu siswa dalam membuat kesimpulan terhadap materi yang diajarkan.

Pembelajaran pada siklus I dan siklus II menunjukkan keaktifan siswa dalam pembelajaran. Setiap kelompok telah menunjukkan kerja sama yang baik, sehingga siswa dapat menemukan konsep yang dipelajari dengan adanya kerja sama antar anggota kelompok dan sedikit bimbingan peneliti.

Fase uraian merupakan lanjutan dari fase sebelumnya. Siswa mempresentasikan hasil kerja kelompok di depan kelas. Peneliti mengarahkan siswa untuk menggunakan bahasa yang tepat. Peneliti memberikan kesempatan kepada siswa untuk mempresentasikan hasil penemuannya dengan menggunakan bahasanya sendiri. Hal ini bertujuan untuk memberikan kesempatan kepada siswa untuk menguraikan pengalamannya, mengekspresikan hasil temuannya dan mengubah pengetahuan siswa yang masih keliru. Hal ini sesuai dengan pendapat D'Augustine dan Smith, Clement dan Batista dalam Chairani (2013) yang menyatakan bahwa pada fase uraian siswa diberikan kesempatan untuk menguraikan pengalamannya, mengekspresikan, dan mengubah pengetahuan intuitif mereka yang tidak sesuai dengan struktur bangun yang diamati.

Kegiatan pada fase orientasi bebas yaitu peneliti mengarahkan siswa untuk mengerjakan latihan soal yang terdapat pada LKS mengenai konsep yang telah mereka temukan. Siswa dihadapkan dengan tugas-tugas yang lebih kompleks dan memerlukan penyelesaian dengan beragam cara. Hal ini sesuai dengan pendapat Chairani (2013) yang menyatakan bahwa fase orientasi bebas bertujuan agar siswa dapat memperoleh pengalaman menyelesaikan permasalahan dengan strategi sendiri.

Fase integrasi dilaksanakan pada kegiatan penutup pembelajaran. Pada fase ini siswa membuat rangkuman tentang materi yang telah dipelajari secara tertulis pada akhir pembelajaran melalui arahan peneliti. Hal ini juga didukung oleh pendapat Barlian (2013) yang menyatakan bahwa peneliti bersama-sama dengan siswa membuat rangkuman/simpulan pelajaran pada akhir pembelajaran. Kegiatan ini bertujuan agar siswa dapat menyatukan hasil pengamatan dan penemuan mereka yang telah didiskusikan dan mengklarifikasi pengetahuan mereka.

Hasil dan pembahasan yang telah diuraikan menunjukkan bahwa indikator keberhasilan tindakan telah tercapai, sehingga dapat disimpulkan bahwa penerapan model pembelajaran Van Hiele dapat meningkatkan hasil belajar pada materi hubungan garis dan sudut di kelas VII SMP Muhammadiyah 1 Palu

Hasil dan pembahasan yang telah diuraikan menunjukkan bahwa aktivitas peneliti dan aktivitas siswa mengalami peningkatan. Hal ini didukung oleh penelitian yang dilakukan Yunus (2011) yang menunjukkan bahwa aktivitas siswa dan aktivitas peneliti mengalami peningkatan dengan adanya penerapan model pembelajaran Van Hiele. Hasil belajar siswa juga meningkat karena siswa tidak lagi mengalami kesulitan pada materi hubungan garis dan sudut yang ditandai dengan siswa dapat menemukan sudut-sudut yang terbentuk jika dua garis sejajar dipotong oleh garis lain, siswa dapat menemukan hubungan/sifat sudut yang terbentuk jika dua garis sejajar dipotong oleh garis lain dan siswa dapat menerapkan hubungan/sifat sudut yang terbentuk jika dua garis sejajar dipotong oleh garis lain. Hal ini menunjukkan bahwa kriteria keberhasilan tindakan telah 
tercapai, sehingga dapat disimpulkan bahwa adanya peningkatan hasil belajar siswa kelas VII SMP Muhammadiyah 1 Palu terhadap materi hubungan garis dan sudut.

\section{KESIMPULAN}

Berdasarkan hasil penelitian dan pembahasan, maka dapat disimpulkan bahwa penerapan model pembelajaran Van Hiele dapat meningkatkan hasil belajar siswa kelas VII SMP Muhammadiyah 1 Palu pada materi hubungan garis dan sudut dengan mengikuti prosedur penelitian yang telah dirancang sebagaimana terlihat pada RPP siklus I dan siklus II. Adapun fase-fase model pembelajaran Van Hiele, yaitu: (1) inquiry, (2) orientasi terarah, (3) uraian , (4) orientasi bebas, dan (5) integrasi.

Kegiatan pada fase inquiry ialah peneliti memberikan gambar dua garis sejajar dipotong oleh garis lain dan meminta siswa untuk mengamati gambar tersebut. Selanjutnya peneliti menggali informasi awal tentang materi hubungan garis dan sudut kepada siswa melalui tanya jawab. Siswa mengerjakan LKS secara berkelompok untuk menemukan konsep materi hubungan garis dan sudut pada fase orientasi terarah. Peneliti memberikan bimbingan kepada kelompok yang mengalami kesulitan dalam mengerjakan LKS. Pada fase uraian siswa mempresentasikan hasil kerja kelompok di depan kelas dan peneliti membimbing siswa untuk menggunakan bahasa yang tepat. Pada fase orientasi bebas siswa mengerjakan latihan secara individu. Kemudian pada fase integrasi peneliti mengarahkan siswa untuk membuat rangkuman konsep materi hubungan garis dan sudut.

\section{SARAN}

Kepada guru khususnya bidang studi matematika diharapkan dapat menjadikan model pembelajaran Van Hiele sebagai salah satu alternatif dalam pelaksanaan pemblajaran yang digunakan untuk meningkatkan hasil belajar siswa terutama pada pelajaran geometri.

Kepada peneliti selanjutnya, dalam pelaksanaan penelitian matematika, diharapkan mencoba menerapkan model pembelajaran Van Hiele pada materi geometri lainnya, untuk mengetahui efektivitas pembelajaran ini dalam upaya peningkatan hasil belajar siswa pada materi matematika khususnya geometri.

\section{DAFTAR PUSTAKA}

Aqib. Z, Diniati. E, Jaiyaroh. S, dan Khotimah.K. (2009). Penelitian Tindakan Kelas. Bandung :Yrama Widya.

Arikunto, S. (2007). Penelitian Tindakan Kelas. Jakatra: Bumi Aksara.

Barlian, I. (2013). Begitu Pentingkah Strategi Belajar Mengajar Bagi Guru? .Jurnal Forum Sosial.[Online].Vol. 6 (1), 6 halaman. Tersedia: http://eprints. unsri.ac.id/2268/2/isi. pdf [22 November 2018]

Chairani, Z. (2013). Implikasi Teori Van Hiele dalam Pembelajaran Geometri. LENTERA Jurnal Ilmiah Kependidikan [Online], Vol. 8, (1), 10 halaman. Tersedia di http://ejurnal.stkipbjm.ac.id/index.php/jpl/article/view/18/17. [9 Desember 2017]

Khotimah.(2013). Meningkatkan Hasil Belajar Geometri dengan Teori Van Hiele. Makalah pada Seminar Nasional matematika dan Pendidikan Matematika di Jurusan 
86 AKSIOMA, Volume 9 Nomor 2, September 2020

Pendidikan Matematika MIPA UNY, [Online]. Tersedia di http: //eprints/uny.ac.id/10723/1/G\%20-\%202.pdf [21 Desember 2017]

Karim, A. (2011). Penerapan Metode Penemuan Terbimbing dalam Pembelajaran Matematika untuk Meningkatkan Pemahaman Konsep dan Kemampuan Berpikir Kritis Siswa Sekolah Dasar. Jurnal Elektronik PGSD Universitas Almuslim [online]. Vol. 1, No. 1.Tersedia: http://jurnal.bull-math.org/ index. php/ Simantap/article/view/37/40 [22 November 2018].

Palolang, F. B. (2014). Penerapan Model Problem Based Learning untuk Meningkatkan Hasil Belajar Siswa pada Materi Panjang Garis Singgung Persekutuan Dua Lingkaran di Kelas VII SMP Negeri 19 Palu .Jurnal Elektronik Pendidikan Matematika

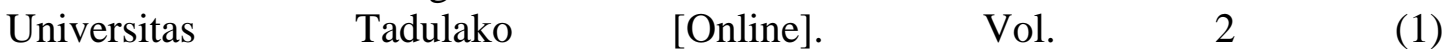
11.hlm.Tersedia:http://jurnal.untad.ac.id/jurnal/index.php/JEMPT/article/view/3232/2 287 [20 November 2018]

Ratumanan. 2003. Model Pembelajaran Menciptakan Proses Belajar Mengajar yang Kreatif dan Efektif. Jakarta: Bumi Aksara

Safrina, K., Ikhsan, M., dan Ahmad, A. (2014). Peningkatan Kemampuan Pemecahan Masalah Geometri melalui Pembelajaran Kooperatif Berbasis Teori Van Hiele. Jurnal Didaktik Matematika [Online], Vol.1 (1), 11 halaman. Tersedia: http://download.portalgaruda.org/article.php?article $=157641 \& 5828 \&$ title=Peningkata n\%20Kemampuan\%20Pemecahan\%20Masalah\%20Geometri\%20melalui\%20Pembel ajaran\%20Kooperatif\%20Berbasis\%20Teori\%20Van\%20Hiele. [21 November 2018]

Thohari, K. (2010). Meningkatkan Kualitas Pembelajaran Geometri dengan Teori VanHiele.[Online].Tersedia:http://4shared.com/office/Ju7sr6f1/khamim_Thohari_van hiele. html [13 November 2017]

Uno, B. H. (2007). Teori Motivasi dan Pengukurannya: Analisis di Bidang Pendidikan. Jakarta: Bumi Aksara.

Yunus, D. (2011). Penerapan model pembelajaran Van Hiele untuk Meningkatkan Hasil Belajar Geometri di Kelas V SDN Ranggeh Pasuruan. Skripsi Sarjana Universitas Negeri Malang, [Online]. Tersedia: http: //library.um.ac.id/ptk/ index.php?mod=detail\&id=51041. [16 Desember 2017] 